\title{
Autologous Blood Transfusion: A Lahad Datu Experience
}

\author{
Otolog Kan Transfüzyonu: Lahad Datu Deneyimi
}

\section{Lin Jett Hau ${ }^{1}$, Ahmad Rusmili Hasyimah Siti ${ }^{1}$, Palamong Binti Nurhafizah ${ }^{1}$, Mat Sani Fauzy Mohd ${ }^{1}$, Han Yeh Poh ${ }^{1}$} Tat Boon Yeap ${ }^{2}$

${ }^{1}$ Department of Anaesthesiology and Intensive Care, Hospital Lahad Datu, Sabah, Malaysia

2 Department of Medicine, Faculty of Medicine and Health Sciences, Universiti Malaysia Sabah, Kota Kinabalu, Sabah, Malaysia

\section{ABSTRACT}

We describe our invaluable experience in managing a 45-year- old gentleman who sustained polytrauma following a motor vehicle accident requiring lifesaving exploratory laparotomy at the district hospital of Lahad Datu, Sabah. Upon requesting blood group and cross match prior to surgery, it was discovered that he was a blood group O Rhesus negative. Unfortunately, our centre did not have 'safe $\mathrm{O}$ ' on hand. Acute normovolemic hemodilution autologous blood transfusion was performed allowing surgery to be performed successfully.

Key Words: Autologous blood transfusion, polytrauma, hemodilution

Received: 10.07 .2018

Accepted: 12.19 .2018

\section{ÖZET}

Sabah, Lahad Datu semt hastanesinde hayat kurtarıcı eksploratif laparotomi gerektiren bir motorlu taşıt kazası sonrası politravması devam eden 45 yaşındaki bir erkek hastayı yönetme konusundaki deneyimimizi sunuyoruz Ameliyattan önce kan grubu ve cross match istendiğinde, kan grubu O Rh negatif olduğ saptandı. Ancak, merkezimizde 'güvenli O' yoktu. Akut normovolemik hemodilüsyon otolog kan transfüzyonu, ameliyatın başarılı bir şekilde yapılmasını sağlamak için yapıldı.

Anahtar Sözcükler: Otolog kan nakli, çoklu travma, hemodilüsyon

Geliş Tarihi: 07.10.2018

Kabul Tarihi: 19.12 .2018

\section{INTRODUCTION}

Lahad Datu is a township located on the east coast of Sabah, Malaysian Borneo. The township shot to prominence in 2013 when there was an armed invasion from the a group of the self-proclaimed Sultan Sulu Jamalul Kiram III of the Philippines, with the killing of Malaysian police officers requiring retaliation by Malaysian security forces.

Hospital Lahad Datu is a 268- bedded district hospital providing specialist services to the surrounding region. It is approximately $270 \mathrm{~km}$ away from Queen Elizabeth Hospital (Sabah State Referral Hospital) located in the capital of Kota Kinabalu. However, the hospital lacks adequate medical supplies due to financial constraints and far distance from the city.

We share our success in the management of a young man who was involved in a polytrauma and had to underwent urgent major abdominal and orthopaedic surgeries with autologous blood transfusion.

\section{CASE REPORT}

A 45- year- old healthy man, weighing $70 \mathrm{~kg}$, presented to the Emergency Department (ED) of Hospital Lahad Datu for polytrauma due to a motor vehicle accident (MVA). He was riding his motorcycle and skidded on a slippery road.

In the ED, he complained of headache and severe abdominal pain. There was no loss of consciousness or ear, nose and throat bleed. His Blood Pressure (BP) was 136/82mmHg, Pulse Rate (PR) 77 beats per minute, Respiratory Rate (RR) of 20 breaths per minute with the Oxygen Saturation (SpO2) of $100 \%$ under room air. Primary survey revealed laceration wounds over the head, deformity of right shoulder, right upper and lower limbs. There was guarding and severe tenderness on palpation of abdomen.

\footnotetext{
Address for Correspondence / Yazışma Adresi: Boon Tat Yeap, MD Department of Medicine, Faculty of Medicine and Health Sciences, Universiti Malaysia Sabah, Kota Kinabalu, Sabah, Malaysia E-mail: boontat@ums.edu.my

(CTelif Hakkı 2019 Gazi Üniversitesi Tıp Fakültesi - Makale metnine http://medicaljournal.gazi.edu.tr/ web adresinden ulaşılabilir.

CCopyright 2019 by Gazi University Medical Faculty - Available on-line at web site http://medicaljournal.gazi.edu.tr/

doi:http://dx.doi.org/10.12996/gmj.2019.52
} 
He had a Hemoglobin $(\mathrm{Hb})$ of $13 \mathrm{~g} / \mathrm{dL}$ Hematocrit $(\mathrm{Hct})$ of $37.5 \%$ and platelet count of $350 \times 10^{9} / \mathrm{L}$. Other biochemical investigations were within normal ranges. Other investigations revealed multiple right rib fractures, right anterior shoulder dislocation, closed right 3rd-5th fracture dislocation of metacarpalphalangeal joint and open right tibial plateau fracture. Contrast Enhanced Computed Tomography (CECT) abdomen was suggestive of small bowel perforation with pneumoperitoneum and intrabdominal collections.

He was planned for an urgent exploratory laparotomy, percutaneous screw fixation of right tibia plateau, and open reduction and k-wire of 3rd-5th metacarpal-phalangeal joint. We requested blood group cross matching in anticipation of intraoperative blood loss when it was discovered that the patient is a Rhesus negative blood group 0 .

We were informed by our blood bank that there was no $O$ negative blood available, but they could provide us two units of $O$ positive blood. Unfortunately a few minutes later, we received a telephone call from ED that there was another patient who required urgent group $O$ blood transfusion for post-partum haemorrhage. A decision was made to perform the Acute Normovolemic Hemodilution (ANH) method of autologous blood transfusion.

We consulted with the surgeon and explained the procedure to the patient. Informed consent was obtained. We aimed for hemodilution to a Hct of $30 \%$. Using the Bourke and Smith equation for allowable blood phlebotomy (ABP), the calculated volume was about $500 \mathrm{mls}(1)$.

Calculation for volume of blood to withdraw :

$\mathrm{Vol}=\underline{\mathrm{EBV} x(\mathrm{Hi}-\mathrm{Hf})}$

Havg

$\mathrm{Hi}=$ initial haematocrit.

$\mathrm{Hf}=$ target haematocrit

Havg $=$ average haematocrit $=(\mathrm{Hi}+\mathrm{Hf}) / 2 \mathrm{EBV}=$ estimated blood volume

After induction of anaesthesia, $500 \mathrm{mls}$ of the patient's autologous blood was collected and kept in a bag. The bag was carefully labelled with the patient's name, identification card number, hospital registration number and kept in the operating theater at room temperature of 15 degrees Celcius. $500 \mathrm{ml}$ Normal Saline $0.9 \%$ then replaced the autologous blood.

Surgery proceeded as planned uneventfully with stable cardiovascular parameters. The BP ranges $88-130 / 40-80 \mathrm{mmHg}$ while the PR was 100-140 $\mathrm{bpm}$. Total duration of anaesthesia and surgery was 5 hours and 4 hours and 38 minutes respectively. Estimated blood loss was between $750 \mathrm{ml}$ to $1000 \mathrm{ml}$. The Hct at the beginning and end of surgery was $37.5 \%$ and $34.7 \%$ respectively.
The patient was given a total of $4000 \mathrm{ml}$ of Normal Saline $0.9 \%$ and $500 \mathrm{ml}$ of Gelafundin. By the end of surgery, the previously collected autologous blood was readministered slowly.

Post operatively the patient was sent to the intensive care unit for continuation of care. He was extubated the next day and discharged to the general ward two days later.

\section{DISCUSSION}

As a district hospital, it is a major challenge to manage patients who require transfusions of rare blood groups especially those requiring urgent care. Patients who sustain polytrauma may not have the luxury of time allowing us to request blood products from other hospitals.

Autologous blood transfusion (ABT) has been widely recognized as a method in managing anemia and surgical blood loss. It is also a method of preventing perioperative allogenic blood transfusion. $A B T$ includes three options: preoperative autologous blood donation (PABD), acute normovolaemic hemodilution $(\mathrm{ANH})$, and intraoperative and postoperative autotransfusion.

Acute Normovolemic Hemodilution (ANH) is the method that we employed. It involves intraoperative removal and storage of a patient's blood after induction of anaesthesia with replacement using crystalloid or colloids. The blood is then transfused when transfusion indications appear during the surgery. It is also the cheapest method of blood procurement, allows us to reduce intraoperative erythrocyte loss and is equally effective compared to other methods $(2,3)$.

\section{CONCLUSION}

Acute normovolemic hemodilution autologous blood transfusion is a safe and effective way to overcome the shortage of blood supply commonly faced in district hospitals. In our case it was done successfully, and we be advocate that it is a method the should be available for general use.

\section{Conflict of interest}

No conflict of interest was declared by the authors.

\section{REFERENCES}

1.Gross JB. Estimating allowable blood loss: correction for dilution Anesth 1983; 56: $577-80$

2.Oppitz PP, Stefani MA. Acute normovolemic hemodilution is safe in neurosurgery. World Neurosurg. 2013;79:719-24.

3.Monk TG, Goodnough LT, Brecher ME, Pulley DD, Colberg JW, Andriole GL, Catalona WJ. Acute normovolemic hemodilution can replace preoperative autologous blood donation as a standard of care for autologous blood procurement in radical prostatectomy, Anesth Analg 1997; 85: 953-8. 